\title{
Investigational Product and Trial Supplies Shipping Handling and Labeling Documentation
}

National Cancer Institute

\section{Source}

National Cancer Institute. Investigational Product and Trial Supplies Shipping Handling and Labeling Documentation. NCI Thesaurus. Code C115705.

Records of the shipping, handling, and labeling of an Investigational Product (IP) and other supplies for a clinical trial. 